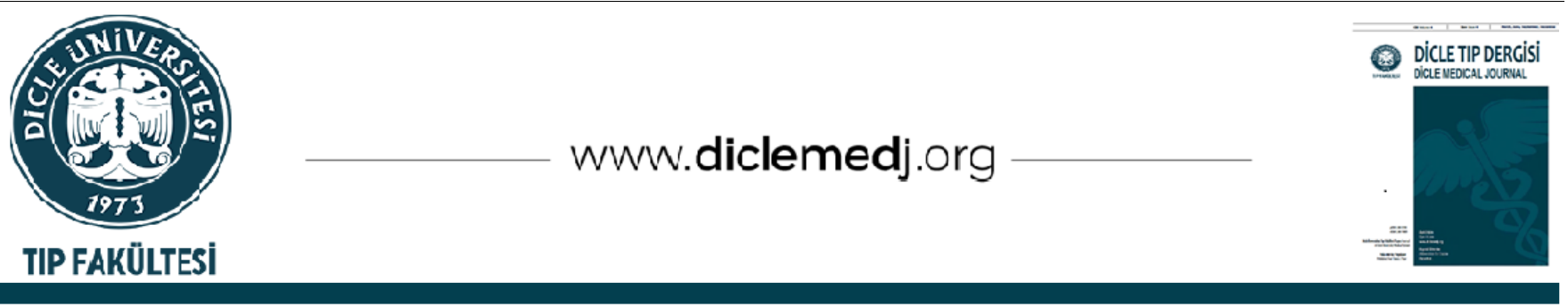

Case Report / Olgu Sunumu

\title{
A Rare Anatomical Location of Necrotizing Enterocolitis; Neonatal Appendicitis
}

\author{
Murat Konak ${ }_{1}$, Mehmet Sarıkaya ${ }_{2}$, Tamer Sekmenli ${ }_{2}^{2}$, Fatma Hicret Tiyek iD $_{3}$, Pınar Karabağlı iD 3 , \\ Hanifi Soylu iD 1
}

1 Division of Neonatology, Department of Pediatrics, Selçuk University, Selçuklu Medical Faculty, Konya, Turkey

2 Department of Pediatric Surgery, Selçuk University, Selçuklu Medical Faculty Konya,Turkey

3 Department of Pathology, School of Medicine, Selcuk University, Konya, Turkey

Received: 04.05.2021; Revised: 01.08.2021; Accepted: 08.08.2021

\begin{abstract}
Necrotizing enterocolitis(NEC) is the most significant gastrointestinal emergency in neonates, particularly affecting those who are premature. Neonatal appendicitis is highly uncommon in term infants and its diagnosis is typically incidental. The clinical presentation of newborn appendicitis is nonspecific and usually mimics that of NEC. Pneumatosis intestinalis is a finding that is extremely specific to NEC; it is very surprising to observe this finding in a patient with acute appendicitis. A 2730-g male infant was born at 39 weeks gestation to a 33-year-old mother. 30 minutes after delivery , the patient exhibited grunting and respiratory distress and was subsequently admitted to the Neonatal Intensive Care Unit. On the 7th day, the patient developed nutrition intolerance. The feeding was discontinued and the nasogastric catheter was switched to free drainage. Abdominal examination and laboratory parameters were not significant, but direct abdominal radiographs showed findings suggesting pneumatosis intestinalis. NEC was considered and the antibiotics were revised accordingly. The department of pediatric surgery was consulted as the patient's abdominal examination and radiographs showed abnormalities suggestive of advanced NEC. The patient was taken into operation, gangrenous appendicitis was detected and an appendectomy was performed. When considering the differential diagnosis of NEC in neonatal patients, especially in term infants, clinicians should be mindful of acute appendicitis. In this study, we present a case of neonatal appendicitis, which is relatively common in pediatric cases but uncommon in the neonatal period, presenting as atypical NEC.
\end{abstract}

Keywords: Neonatal Appendicitis, Necrotizing Enterocolitis, Newborn, Pneumatosis intestinalis

DOI: 10.5798/dicletip.988089

Correspondence / Yazıșma Adresi: Murat Konak, Division of Neonatology, Department of Pediatrics, Selcuklu Medical Faculty, Selcuk University, Konya, Turkey e-mail: drmkonak@hotmail.com 


\section{Nekrotizan Enterokolitin Nadir Bir Lokalizasyonu: Neonatal Apendisit}

Öz

Nekrotizan enterokolit (NEK), özellikle prematüre bebekleri etkileyen ve term bebeklerde oldukça nadir görülen neonatal dönemdeki en önemli gastrointestinal acil durumdur. Ek olarak, neonatal apandisit de çok nadirdir ve sıklıkla rastlantısal olarak tanımlanır. Yenidoğanda apandisitin klinik bulguları nonspesifiktir. Pnömatozis intestinalis, NEK'in son derece spesifik bulgularından biridir ancak apandisitte görülmesi çok ilginçtir. 2730 gramlık bir erkek bebek, 33 yaşındaki bir anneden 39. gestasyonel haftasında doğdu. 30 dakika sonra hastada inleme ve solunum sıkıntısı gözlenmesi üzerine Yenidoğan Yoğun Bakım Ünitesine yatışı yapıldı. Hastanın yaşamının 7. gününde beslenme intoleransı gelişti. Beslenme kesildi ve nazogastrik kateter serbest drenaja alındı. Karın muayenesi ve laboratuar parametreleri normaldi, ancak batın grafisinde şüpheli pnömatozis intestinalis görüldü. Nekrotizan enterokolit düşünüldü ve antibiyotik revizyonu yapıldı. Hastanın karın muayenesi ve karın filminin bozulması nedeniyle ileri evre NEK tanısı ile Çocuk cerrahisine konsülte edildi. Operasyonda sadece gangrenöz apandisit tespit edilerek apendektomi yapıldı. Yenidoğan ünitelerinde ürkütücü bir tablo olan NEK ayrıcı tanısında özellikle term bebeklerde akut apendisit akılda tutulmalıdır. Bu yazı da pediatrik olgularda nispeten sık karşılaşılan ancak yenidoğan döneminde nadir görüldüğü için vurgulanmak istenen ayrıca atipik NEK tablosunda ortaya çıkan bir neonatal apandisit olgusu sunulmuştur.

Anahtar kelimeler: Neonatal apendisit, Nekrotizan Enterokolit, Yenidoğan, Pnömotozis intestinalis.

\section{INTRODUCTION}

Necrotizing enterocolitis (NEC) is the most significant gastrointestinal emergency in the neonatal period, especially in premature babies $^{1,2}$. NEC typically occurs in the terminal ileum and the proximal colon, which are sites with less vascularity, suggesting an issue in the circulatory system that could be liable for the disease. Studies regarding NEC pathogenesis highlight the importance of ischemia. The hypoxic/ischemic disturbance is directly responsible for intestinal mucosal damage, penetration of the intestinal barrier and promotion of bacterial invasion, ultimately leading to inflammatory cascade activation ${ }^{1}$.

In the pediatric population, excluding newborn patients, nearly all cases of appendicitis are seen subsequent to obstruction of the lumen ${ }^{3}$. In newborns and cases such as ours, hypoxia is an important trigger factor for appendicitis ${ }^{4}$. The clinical presentation of appendicitis in the newborn is nonspecific and typically mimics that of $\mathrm{NEC}^{5}$. The most common findings are abdominal distension, tenderness, feeding intolerance, and fever ${ }^{5}$. Approximately $50 \%$ of cases occur in premature neonates and a third of cases are initially diagnosed as NEC 5 .
Delaying the diagnosis may often lead to unrecognized perforation. Up to $85 \%$ of cases develop perforation, but pneumoperitoneum is recognized in just half of perforated cases ${ }^{5}$. We herein presented a non-perforated but gangrenous neonatal appendicitis case.

\section{CASE PRESENTATION}

A 2730-g male infant was born at $390 / 7$ weeks gestation to a 33-year-old mother who had 3 prior spontaneous abortus. The prenatal laboratory and routine history were insignificant; prenatal ultrasound exhibited normal findings. Following spontaneous onset of labor, our patient was delivered vaginally. As no problems were experienced during and following birth, the patient stayed beside his mother. 30 minutes after birth, it was noticed that the patient was experiencing grunting and respiratory distress; he was subsequently admitted to Neonatal Intensive Care Unit. In the follow-up, due to progression of the respiratory distress, the patient was believed to have a congenital heart disease and was transferred to our clinic. After admission to our clinic, the patient was intubated and monitored with mechanical ventilation. Physical examination revealed no pathology other than respiratory 
distress. Ampicillin/amikacin treatment was started in the patient for early neonatal sepsis. Echocardiography showed normal findings. He was extubated on day 2 of admission, which was the fifth day of life. Full enteral feeding was achieved by promoting nutrition. The patient developed nutrition intolerance on the 7 th day of life. The feeding was discontinued and the nasogastric catheter was switched to free drainage. Abdominal examination and laboratory parameters were insignificant, but direct abdominal radiograph exhibited findings suggestive of pneumatosis intestinalis (Figure 1). After 6 hours, a follow up abdominal radiograph showed progression of pneumatosis intestinalis (Figure 2). Of the laboratory findings, while WBC remained the same, CRP increased to $95 \mathrm{mg} / \mathrm{dl}$. Necrotizing enterocolitis was considered and the antibiotics were revised accordingly. The department of pediatric surgery was consulted. Since the patient showed signs of peritoneum irritation and progressive abdominal distention, abdominal radiography was performed again. According to the findings on physical examination and abdominal film, the patient was diagnosed with NEC and subsequently taken into operation. During the operation, gangrenous appendicitis was observed and an appendectomy was performed. Histopathological examination of the appendix wall showed significant transmural neutrophil infiltration and necrotic changes in the mucosa (figüre 2). On the 2nd postoperative day, the patient's abdominal distention and high CRP level persisted; he was then reoperated and necrosis was detected on the antimesenteric splenic flexure (figure 3). The necrotic area was excised and a colostomy was performed. Blood culture showed no signs of microbial growth. On the 4 th postoperative day, the patient's feeding was opened and he did not have any additional complaints. On the 14th postoperative day, the patient's clinical condition had stabilized and he was discharged on follow-up and an appointment to close his colostomy. Pathological evaluation showed gangrenous appendicitis and necrosis of the bowel. During the second operation, a biopsy was performed from pathological and normal areas to exclude hirschsprung disease. Ganglion cells were detected.

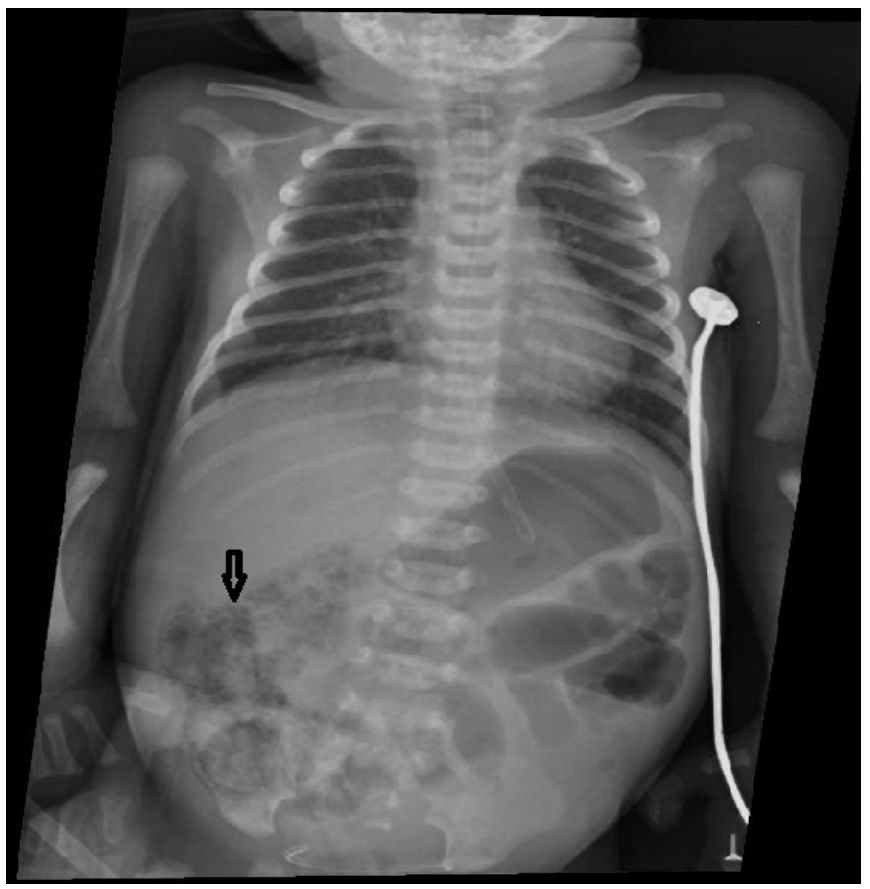

Figure 1. Abdominal radiograph demonstrating initial of pneumatosis intestinalis.

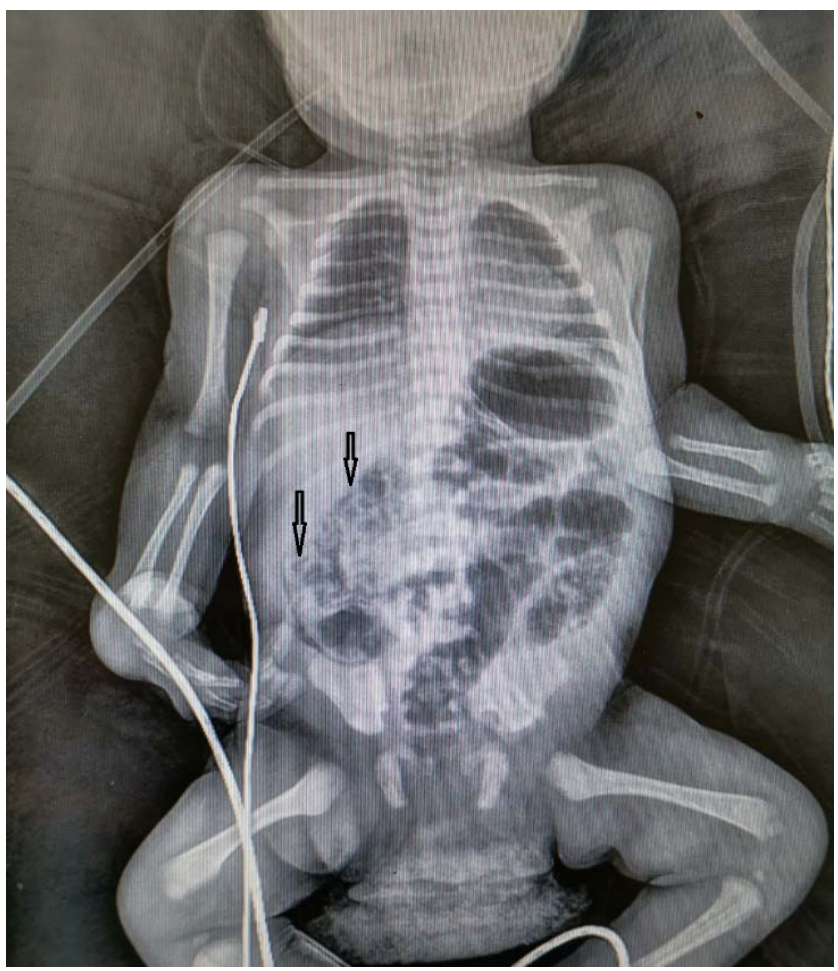

Figure 2. a) 


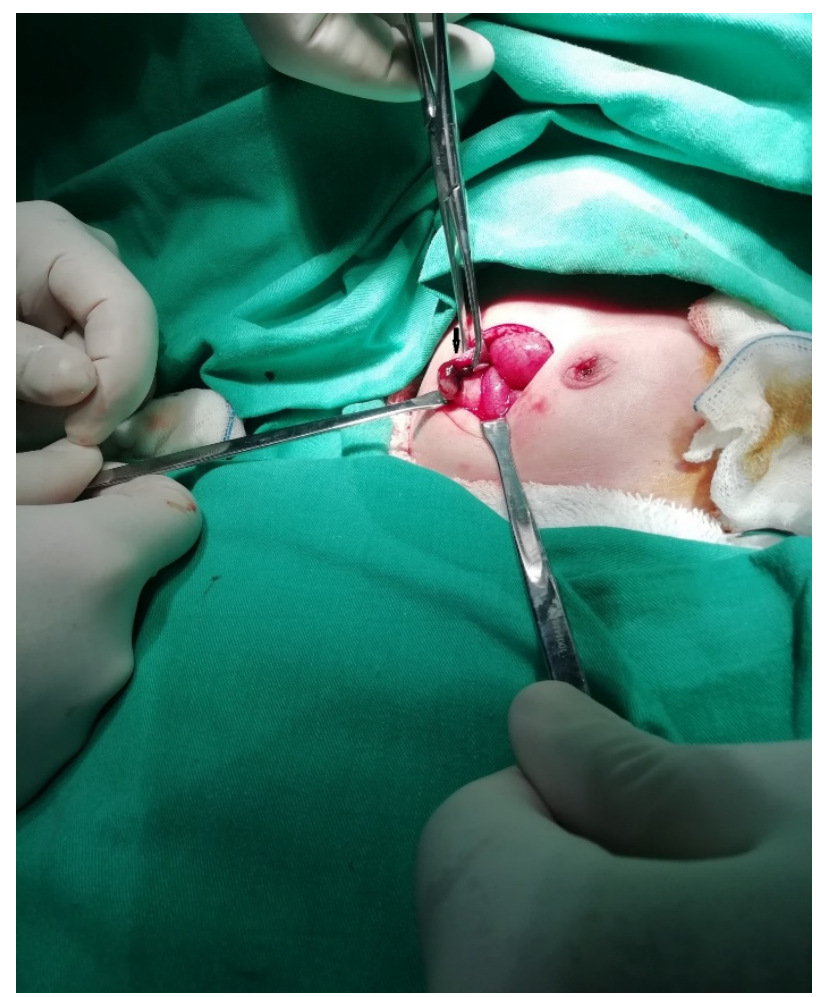

Figure 2. b)

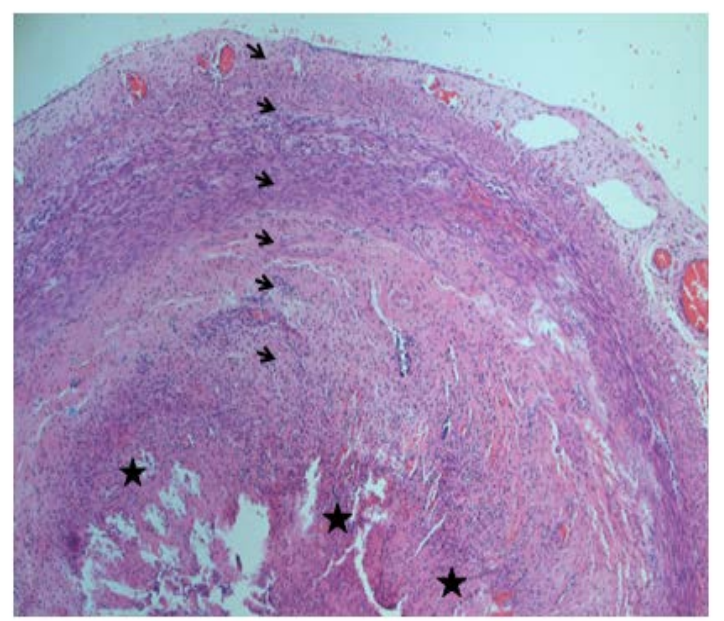

Figure 2. c)

Figure 2. a) Abdominal radiograph demonstrating increased and advanced pneumatosis intestinalis b) Intraoperative picture demonstrating gangrenous appendicitis. c) Significant neutrophil infiltration and necrotic changes in the appendix wall (HE X 100).

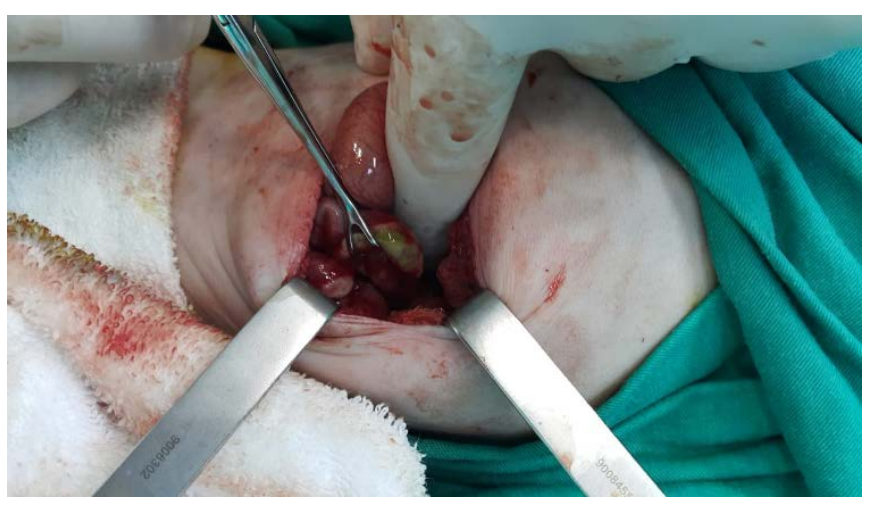

Figure 3. Intraoperative picture demonstrating the necrosis of splenic flexure antimesenteric side.

\section{DISCUSSION}

Appendicitis is one of the most frequent causes of acute abdominal pain requiring surgery in children above 1 year of age. However, neonatal appendicitis is highly rare. Atypical clinical symptoms associated with appendicitis in the neonatal period make early diagnosis difficult, and thus, neonatal appendicitis is associated with high rates of perforation and mortality ${ }^{6}$. In addition, compared to older patients, laboratory tests have less significance for diagnosis in the neonatal period7. Several risk factors for NEC, such as hypoxemia or ischemia, are also believed to be associated with "neonatal appendicitis", combined with the fact that half of infants with isolated appendicitis are preterm ${ }^{4}$. In our case, it was shown that hypoxemia was present before referral, therefore, it was most likely caused by congenital heart disease. For this reason, the etiology of this NEC case was thought to be secondary to hypoxia. These factors suggest that this could be a NEC case restricted to the appendix, or the beginning stage of NEC.

In our case study, appendicitis initially appeared followed by bowel necrosis. This finding supports the results from previous reports. Raveenthiran's study published in 2015 inquired whether neonatal appendicitis could be a form of NEC. Our case presentation could shed light on this question ${ }^{5}$. 
In the literature, it is seen that many neonatal appendicitis cases occur with a NEC-like clinical picture ${ }^{5,8}$. As in our case, many cases were diagnosed with NEC and intraoperatively reported to be neonatal appendicitis.

Neonates with perforated appendicitis are usually diagnosed intraoperatively. Diagnostic delay may lead to unrecognized perforation. Perforation of the appendix has also been associated with disease processes with increased intraluminal pressure and may be the initial presentation of Hirschsprung disease and cystic fibrosis ${ }^{8}$. In our case, pathological evaluation ruled out hirschsprung disease, but the suspected cystic fibrosis was detected in the neonatal screening program. Furthermore, pneumatosis intestinalis is a finding that is extremely specific to necrotizing enterocolitis; however, it is very surprising to observe it in appendicitis. When considering the differential diagnosis of NEC in neonatal patients, especially in term infants, clinicians should be mindful of acute appendicitis. In this study, we present a case of neonatal appendicitis, which is relatively common in pediatric cases but uncommon in the neonatal period, presenting as atypical NEC.

Abbreviations: NEC: Necrotizing enterocolitis; CRP: C-reactive protein; WBC: White blood cells

Informed Voluntary Consent Form: Consent form was taken from the patient.

Conflict of Interest: No conflict of interest was declared by the authors.

Financial Disclosure: No financial disclosure was declared by the authors.

\section{REFERENCES}

1. Hackam D and Caplan M. Necrotizing enterocolitis: pathophysiology from a historical context. Seminars in pediatric surgery. Elsevier, 2018, p. 11-8.

2. Alganabi M, Lee C, Bindi E, Li B and Pierro A. Recent advances in understanding necrotizing enterocolitis. F1000Research. 2019; 8.

3. Coran AG, Caldamone A, Adzick NS, Krummel TM, Laberge J-M and Shamberger R. Pediatric surgery Ebook. Elsevier Health Sciences, 2012.

4. Haider F, Ayoub B, Al Kooheji M, Al Juffairi M and Al-Shaikh S. Perforated acute appendicitis with no peritonitis in a premature baby: a case report. Journal of medical case reports. 2017; 11: 1-4.

5. Raveenthiran V. Neonatal appendicitis (part 1): a review of 52 cases with abdominal manifestation. Journal of neonatal surgery. 2015; 4.

6. Karaman A, Çavuşoğlu YH, Karaman I and Cakmak 0 . Seven cases of neonatal appendicitis with a review of the English language literature of the last century. Pediatric surgery international. 2003; 19: 707-9.

7. Badhani A and Singh SK. Appendicular perforation in a neonate: a case report. International Surgery Journal. 2019; 6: 1800-2.

8. Bengtsson B-OS and van Houten JP. Neonatal vermiform appendicopathy. American journal of perinatology. 2015; 32: 683-8. 